\title{
Hypercholesterolemia, as a Predictor Factor of Severe Acute Pancreatitis
}

\author{
Bogdan Socea', Alexandra Bolocan², Ovidiu Gabriel Bratu³, Dan Nicolae Paduraru², \\ Camelia Cristina Diaconu4, Vlad Denis Constantin
}

\begin{abstract}
Dyslipidemia constitutes a well-known factor that can lead to acute pancreatitis. Hypertrigliceridemia and hypercholesterolemia are part of dyslipidemia. In a prospecitve study, we analyzed the role of hypercholesterolemia in triggering episodes of acute pancreatitis and the capacity of cholesterol blood level to predict the severity and the evolution of acute pancreatitis.

In our prospective study, a preexistent cholesterol blood level above $240 \mathrm{mg} / \mathrm{dl}$ proved to be a trigger for pancreatitis and an increasing cholesterol level in evolution predicts a pancreatitis with organ failure (moderately-severe or severe).
\end{abstract}

Keywords: hypercholesterolemia, acute pancreatitis, severe pancreatitis

\section{Rezumat}

Dislipidemia reprezintă un factor etiologic bine-cunoscut în pancreatita acută. Hipertrigliceridemia și hipercolesterolemia reprezintă elemente ale dislipidemiei. Într-un studiu prospectiv, am analizat rolul hipercolesterolemiei în declanșarea episoadelor acute de pancreatită acută și capacitatea predictivă a nivelului sanguin al colesterolului pentru severitatea evoluției pancreatitei.

În studiul nostru prospectiv, un nivel preexistent al colesterolemiei de peste $240 \mathrm{mg} / \mathrm{dl}$, s-a dovedit a fi incriminat în declanșarea pancreatitei acute și o colesterolemie în creștere în evoluția pancreatitei poate prevedea o insuficiență de organ (pancreatită acută moderat-severă sau severă).

Cuvinte cheie: hipercolesterolemia, pancreatită acută, pancreatită severă

\section{INTRODUCTION}

Acute pancreatitis is a potentially severe disease that could lead to multiple organ dysfunction or failure. In our surgical clinic we observed lately an increasing number of patients with acute pancreatitis, and, among them, the rate of moderately-severe and severe outcome has become higher. These forms are classified according to Acute Pancreatitis Classification Working Group, held

\footnotetext{
1 Department of Surgery, "Sf. Pantelimon" Emergency Clinical Hospital, "Carol Davila" University of Medicine and Pharmacy, Bucharest, Romania

${ }^{2}{ }^{\prime I}{ }^{\text {rd }}$ Department of Surgery, Emergency University Hospital, „Carol Davila" University of Medicine and Pharmacy, Bucharest, Romania

${ }^{3}$ Department of Urology, Central Clinical Military Hospital, „Carol Davila" University of Medicine and Pharmacy, Bucharest, Romania

${ }^{4}$ Department of Internal Medicine, Emergency Clinical Hospital, "Carol Davila" University of Medicine and Pharmacy, Bucharest, Romania
}

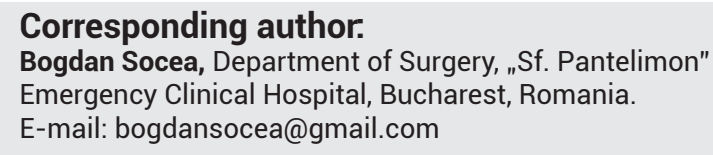


in Atlanta, in 2012, that introduced a new concept, of moderately-severe pancreatitis, compared to the initial classification from $2007^{1-3}$. Severe acute pancreatitis (pancreatitis with unique or multiple persistent organ failure - over 48 hours) is responsible of approximately $15 \%$ from all acute pancreatitis. The mortality of this form is $7-10 \% 4,5$.

Moderately-severe pancreatitis means acute pancreatitis with transient organ failure, under 48 hours.

The most common causes of acute pancreatitis are: gallstones, alcohol consumption, dyslipidemia, iatrogenic pancreatitis, posttraumatic or postoperative.

Measuring cholesterol level is an effective method for identifying individuals with elevated triglyceride levels. Individuals with severe hyper-triglyceridemia have a substantially higher risk for developing coronary heart disease and acute pancreatitis than individuals with lower triglyceride levels ${ }^{6,7}$.

There are discussions in the literature whether hypercholesterolemia in some specific cases is a trigger of a consequence of acute pancreatitis. We analyzed only the patients with a preexistent determination of total cholesterol level.

\section{MATERIALS AND METHOD}

We analyzed all the patients with acute pancreatitis admitted in the Surgical Department of "Sf. Pantelimon” Emergency Clinical Hospital in a five years interval, 2013-2017. We excluded biliary and alcohol-induced pancreatitis.

We included in our study a total number of $237 \mathrm{ca}-$ ses of acute pancreatitis. The inclusion criteria were: non-biliary and non-alcoholic pancreatitis respecting the definition (abdominal pain and elevated pancreatic enzyme blood levels above three times of normal values).

The study was a prospective one. We collected any total cholesterol level determination before the moment of admission, on the admission day, after 72 hours (day four) and on day 7.

We treated and observed the patients, especially for organ dysfunction or failure (transitory or persistent), which are the elements of classification for moderately-severe and severe forms. In our study, none of these patients underwent surgical interventions at in their first week of admission. We had no criteria for operation (no complications requiring surgery in the first moments). A number of 11 patients required surgical procedures for infected necroses in the second of third week of their first admission. Some patients suffered readmissions and surgical procedures for pancreatic pseudocysts, but all these evolution did not affect the study results.

\section{RESULTS AND DISCUSSIONS}

From the 237 patients, there were 149 men and 88 women (Figure 1).

The disposition of age groups shows a predilection of onset at over 50 years for women (mean age for women in our study was 74.7 years) and over 30 years of age for men (mean age 58.3). The later onset for women could be explained by estrogen levels and the higher incidence of dyslipidemia and hypercholesterolemia after menopause ${ }^{8,9}$. We excluded a case of a pregnant woman ${ }^{10}$.

The diagram of age groups can be seen on Figure 2.

The mean value of total cholesterol blood level at admission was $241 \mathrm{mg} / \mathrm{dl}$. The mean values are different between men and women (higher for men $249 \mathrm{mg} / \mathrm{dl}$ vs. $237 \mathrm{mg} / \mathrm{dl}$ for women).

From all the 237 patients included in study, a number of 206 patients (87\%) had total blood cholesterol level above $240 \mathrm{mg} / \mathrm{dl}$ at admission time. This could be

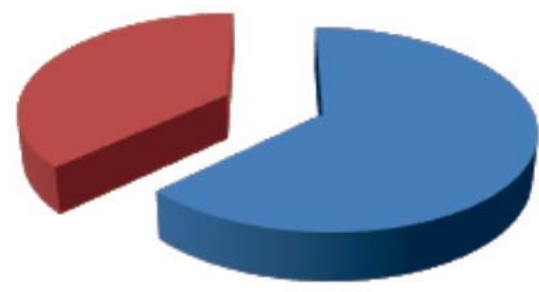

Male

Female

Figure 1. Sex distribution.

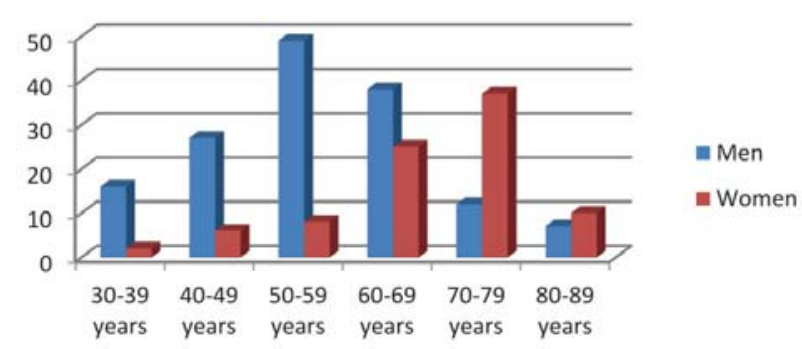

Figure 2. Age distribution for men and women. 


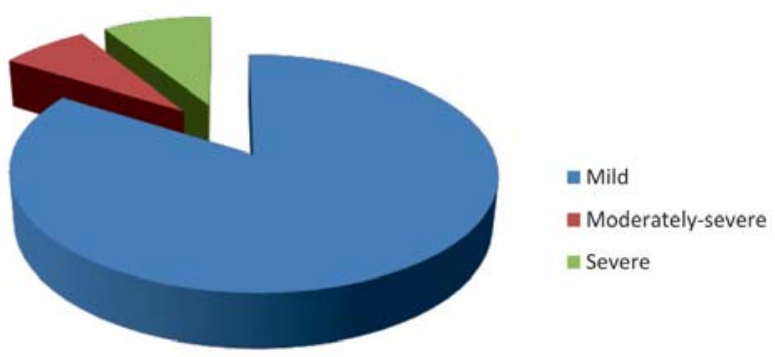

Figure 3. Forms of pancreatitis.

considered a cut-off value for increased risk of developing acute pancreatitis. Comparing the results, a study form Spain found that prevalence of hypercholesterolemia ranged from 50 to $84 \%$ in diabetics, $64-74 \%$ with coronary heart disease, $40-70 \%$ in stroke patients, and $60-80 \%$ in those with peripheral artery disease ${ }^{11}$. A prevalence of $87 \%$ is above all these conditions. Some studies for hypercholesterolemia in general population found levels between $20 \%$ and $60 \%$, depending on alimentary habits and direct corelated with obesity ${ }^{12,13}$.

We could not find any other triggers that could be involved in ethiopathogeny of the patients from the study.

Severe acute pancreatitis developed in 21 cases (8.86\%) and moderately-severe in 17 cases (7.17\%) (Figure 3). The most encountered organ failures were renal, pulmonary and hepatic. Some cases had pancreatic encephalopathy, which seems to be more related to toxic (alcohol) induced pancreatitis than biliary or dyslipidemic ones ${ }^{14}$.

Together, moderately-severe and severe pancreatitis are responsible for $16 \%$ of cases, data concordant to literature (approximately 20\% [1]). The mortality was $11.7 \%$ for moderately-severe form (2 cases), respectively $23.8 \%$ (5 patients) with severe pancreatitis, comparable with that mentioned in literature ${ }^{15}$. All the 5

\section{References}

1. Banks PA, Bollen TL, Dervenis C, Gooszen HG, Johnson CD, Sarr MG, Tsiotos GG, Vege SS; Acute Pancreatitis Classification Working Group. Classification of acute pancreatitis - 2012: revision of the Atlanta classification and definitions by international consensus. Gut. 2013 Jan; 62(1):102-11.

2. Sarr MG, Banks PA, Bollen TL, Dervenis C, Gooszen HG, Johnson CD, Tsiotos GG, Vege SS. The new revised classification of acute pancreatitis 2012. Surg Clin North Am. 2013 Jun; 93(3):549-62.

3. Choi JH, Kim MH, Oh D, Paik WH, Park DH, Lee SS, Seo DW, Lee SK. Clinical relevance of the revised Atlanta classification focu- patients that died of severe pancreatitis had increased abdominal pressure ${ }^{16}$.

We compared the cholesterol blood levels in day 3 and day 7 to the admission value for patients with mild pancreatitis, on one hand, and for patients that developed moderately-severe and severe forms, on the other hand. We did not found any major changes in cholesterol levels, in evolution of patients with mild form of disease.

For the group of patients with organ failure, no matter of organ failure persistence, we found an increased value of cholesterol level with a mean rate of $21 \%$ at day 3 and $53 \%$ at day 7 . So, increasing values of total blood cholesterol in evolution of patients with acute pancreatitis can predict an evolution to severity. This is concordant to some studies in literature ${ }^{17}$.

An elevated cholesterol level at admission was not associated with increased mortality in our cohort, which is in accord with the findings of some recent metaanalysis regarding triglycerides levels ${ }^{18,19}$.

\section{CONCLUSIONS}

Hypercolesterolemia is a trigger for acute pancreatitis. A blood level over $240 \mathrm{mg} / \mathrm{dl}$ could be considered a risk factor.

Increasing values of cholesterol blood levels during evolution predicts an poor outcome and an evolution to organ failure (transient - moderately-severe pancreatitis or persistent - severe pancreatitis) with high mortality.

Compliance with ethics requirements: The authors declare no conflict of interest regarding this article. The authors declare that all the procedures and experiments of this study respect the ethical standards in the Helsinki Declaration of 1975, as revised in 2008(5), as well as the national law. Informed consent was obtained from all the patients included in the study. sing on severity stratification system. Pancreatology. 2014 Aug 19. pii: S1424-3903(14)00963-6.

4. Charbonney E, Nathens AB. Severe acute pancreatitis: a review. Surg Infect (Larchmt). 2008; 9(6):573-8.

5. Hamada T, Yasunaga H, Nakai $Y$, Isayama H, Horiquchi H, Fushimi K, Koike K. Japanese severity score for acute pancreatitis well predicts in-hospital mortality: a nationwide surwey of 17901 cases. J Gastroenterol. 2013.

6. Christian JB, Bourgeois NE, Lowe KA. Cholesterol screening in US adults and awareness of high cholesterol among individuals with severe hypertriglyceridemia: National Health and Nutrition 
Examination Surveys 2001-2008. J Cardiovasc Nurs. 2015 JanFeb;30(1):26-34. doi: 10.1097/JCN.0000000000000101.

7. Socea B, Radu L, Clenciu D, Tenea Cojan TS, Baleanu V, Ene CG, Girgavu SR, Vladu IM. The utility of visceral adiposity index in prediction of metabolic syndrome and hypercholesterolemia. Rev. Chim., 2018, 69(11):4012-4.

8. Marchi R, Dell'Agnolo CM, Lopes TCR, Gravena AAF, Demitto MO, Brischiliari SCR, Borghesan DHP, Carvalho MDB, Pelloso SM. Prevalence of metabolic syndrome in pre- and postmenopausal women. Arch Endocrinol Metab. 2017 Mar-Apr;61(2):160-166. doi: 10.1590/2359-3997000000253.

9. Lee JS, Hayashi K, Mishra G, Yasui T, Kubota T, Mizunuma H. Independent association between age at natural menopause and hypercholesterolemia, hypertension, and diabetes mellitus: Japan nurses' health study. J Atheroscler Thromb. 2013;20(2):161-9.

10. Popescu I, Banacu M, Popescu M, Pacu I, Gheorghiu D, Davitoiu $B$, Socea B, Dimitriu MCT. Acute pancreatitis during pregnancy - a case report. Arch Balk Med Union, 2017, 52(4):471-4.

11. De la Sierra A, Pintó X, Guijarro C, Miranda JL, Callejo D, Cuervo J, Subirà R, Rubio M. Prevalence, Treatment, and Control of Hypercholesterolemia in High Cardiovascular Risk Patients: Evidences from a Systematic Literature Review in Spain. Adv Ther. 2015 Oct;32(10):944-61. doi: 10.1007/s12325-015-0252-y.

12. Pająk A, Szafraniec K, Polak M, Polakowska M, Kozela M, Piotrowski W, Kwaśniewska M, Podolecka E, Kozakiewicz K, Tykarski A, Zdrojewski T, Drygas W; WOBASZ Investigators. Changes in the prevalence, treatment, and control of hypercho- lesterolemia and other dyslipidemias over 10 years in Poland: the WOBASZ study. Pol Arch Med Wewn. 2016 Jul 19;126(9): 642-652. doi: 10.20452/pamw.3464

13. Abujbara $M$, Batieha $A$, Khader $Y$, Jaddou $H$, El-Khateeb $M, A j-$ louni K. The Prevalence of Dyslipidemia among Jordanians. J Lipids. 2018 Oct 28;2018:6298739. doi: 10.1155/2018/6298739.

14. Constantin VD, Carâp A, Socea B, Bobic S. Pancreatic encephalopathy - a rare complication of severe acute biliary pancreatitis. Journal of Mind and Medical Sciences, 2014, 1(1):40-51.

15. Shen X, Ke L, Yang D, Sun J, Tong Z, Li B, et al. The prognostic value of the strong ion gap in acute pancreatitis. J Crit Care. 2016;36:140-5.

16. Carâp A, Popa F, Socea B, Moculescu C, Păunică-Panea G, Păun I, Budu V, Constantin V. Risk factors for increased intra-abdominal pressure in severe acute pancreatitis. Arch Balk Med Union, 2015, 50(4):498-502.

17. Wu Q, Fu M, Zheng $K$, Bo H, Yang H, Zhong X, Liang G, Xu Y, Hao $B$, Hu Z, Zhang Z, Jin X, Kang Y. Elevated triglycerides level in hospital stay as a risk factor of mortality in patients with severe acute pancreatitis. PLoS One. 2018 Nov 29;13(11):e0207875. doi: 10.1371/journal.pone.0207875.

18. Kiss L, Fur G, Matrai P, Hegyi P, Ivany E, Cazacu IM, et al. The effect of serum triglyceride concentration on the outcome of acute pancreatitis: systematic review and meta-analysis. Sci Rep. 2018;8(1):14096.

19. Rawla P, Sunkara T, Thandra KC, Gaduputi V. Hypertriglyceridemia-induced pancreatitis: updated review of current treatment and preventive strategies. Clin J Gastroenterol. 2018. 